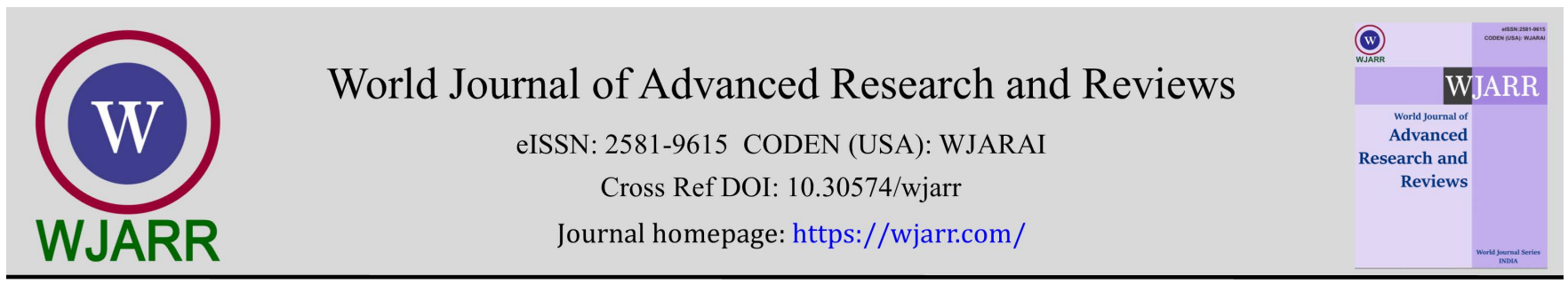

(REVIEW ARTICLE)

\title{
Bioplastic for future: A review then and now
}

\author{
Manali Shah *, Sanjukta Rajhans, Himanshu A. Pandya and Archana U. Mankad \\ Department of Botany, Bioinformatics and Climate Change Impacts Management, School of Science, Gujarat University, \\ Ahmedabad, Gujarat, India.
}

World Journal of Advanced Research and Reviews, 2021, 09(02), 056-067

Publication history: Received on 15 January 2021; revised on 11 February 2021; accepted on 13 February 2021

Article DOI: https://doi.org/10.30574/wjarr.2021.9.2.0054

\begin{abstract}
Petrochemical based plastics have been widely used as packaging materials, as they have good barrier properties, stiffness, tensile strength \& tear strength. Although in great demand plastics have many disadvantages like very low water vapour transmission rate, non- biodegradability etc. which further causes environmental pollution. Keeping in mind about the pollution and harm caused to the nature, newer concepts about the use of bio-plastics came into force. Bio-plastics are produced from the biological sources such as potato, potato peels, corn, sugarcane, wheat, rice, banana peels etc. These plastics are environment friendly \& biodegradable, and are safer option than the petroleum-based plastics. These biodegradable plastics break down into carbon dioxide, water \& inorganic compounds and degrade completely. The time-line, sources and other important details about the bio-plastics have been presented in this review paper.
\end{abstract}

Keywords: Bioplastic; Biodegradable; Renewable; Eco-friendly; Plasticizers

\section{Introduction}

Due to their versatile, inexpensive, lightweight and excellent thermal properties; petrochemical based plastics such as Poly Ethyl Terepthalate (PET), Poly Butylene Terepthalate (PBT), Polypropylene (PP), Polystyrene (PS), Polyvinyl Chloride (PVC) are widely used in our day-to-day life $[1,2,3]$.

Plastics are used to make products such as water bottles, coffee cups, forks, knives, plastic bags to carry groceries, etc. Petrochemical based plastics are not eco-friendly because of their high content of carbon footprint [4]. Properties like cheapness, durability and lightness make plastics far more useful than the metals, wood, papers etc. They are useful in almost all the industrial fields. Excessive use of plastics has caused severe impacts to the environment, and it is estimated that about 34 million tons of plastics are produced per year by humans. Out of that only $7 \%$ is recycled and the remaining 93\% is dumped into the landfills, oceans and seas [5]. In 2015, more than 300 million tons of plastic was used in the world [6]. The incineration or burning of plastic liberates various toxic emissions such as carbon dioxide and methane, these greenhouse gases affect the climate worldwide [7]. Petrochemical based products cause many problems like accumulation of waste in land area, in natural habitats like sea, oceans etc [8]. Due to plastic pollution, humans are also suffering from the disturbance of thyroid hormone levels [9]. Due to the use of chemical additives during the production of plastic, they are toxic and carcinogenic. Efforts to reduce plastic consumption has occurred in many areas which have further promoted the recycling of plastic. Additives such as phthalate plasticizers and brominated flame retardants are used in the production of plastics [10]. Plasticizers are substances that are added to plastics to increase their flexibility, durability, transparency and longevity. Therefore, now scientists are looking for other alternative options.

${ }^{*}$ Corresponding author: Manali Shah

Department of Botany, Bioinformatics and Climate Change Impacts Management, School of Science, Gujarat University, Ahmedabad, Gujarat, India.

Copyright (C) 2021 Author(s) retain the copyright of this article. This article is published under the terms of the Creative Commons Attribution Liscense 4.0. 


\section{Timeline of plastics}

2.1. Parkesine: In 1862, Alexander Parkes produced first man-made plastic called as Parkesine. It was a biological material derived from cellulose that once prepared and molded, it maintained its shape as it cooled down.

2.2. Celluloid: In 1868, John Wesley Hyatt invented celluloid (resultant from cellulose and alcoholised camphor) as an alternative for the ivory in billiard balls. But the flexible film he developed was not strong enough to be used as an alternative to billiard balls. The newly formed substance i.e., celluloid was easy to be modeled with heat and pressure and it became famous as it was the 1st flexible photographic film used for still photography and motion pictures [11].

2.3. Bakelite - Formaldehyde Resins: Formaldehyde was the next foundation that evolved in the technology of plastics after cellulose nitrate. In 1897, many struggles were done to produce white chalkboards directed to casein (milk protein mixed with formaldehyde) plastics. Galalith and Erinoid were the two examples of synthetic plastic materials of that time. In 1899, Arthur Smith established British Patent for "phenol formaldehyde resins" and in 1907, Leo Hendrik Backeland improved phenol formaldehyde resin and invented 1st synthetic resin, called as Bakelite [12].

2.4. Polyvinyl chloride (PVC): French physicist Victor Regnault discovered PVC in 1912.

2.5. Cellophane: Edwin Brandenberger used viscose to form cellophane in 1913. It was his idea that created transparent packaging for food items.

Polymethyl methylacrylate (PMMA): Barker and Skinner created PMMA. In 1924 it was sold by Rohm, under the name of Plexiglas.

2.6. Polyethylene (PE): It was discovered by E.W. Fawcett and R.O. Gibson in 1933. It is the most commonly used plastic in the world.

2.7. Polyurethane (PUR): In 1937, Dr. Otto Bayer developed PUR.

2.8. Polystyrene (PS): Ray Mclntire developed Polystyrene in 1944 by chance when he was working on flexible rubber.

2.9. Polypropylene (PP): Working for Montedison, Giulio Natta (1963 Nobel Prize with Karl Ziegler) discovered a catalyst what is dubbed as the "Ziegler-Natta". This catalyst was able to produce polypropylene with high mechanical resistance, inert to chemical aggression, and able to withstand temperatures above $100^{\circ} \mathrm{C}$ [13].

\section{Bioplastic and its sources}

Bioplastics are biodegradable plastics made from the renewable sources [4]. Renewable sources such as potato starch, corn starch, fibres obtained from pineapple, jute, hemp, banana stems [14,15] cassava [16], newspaper pulp [17], waste paper [18], Prosopis juliflora [19], citrus waste [20], cyanobacteria [21], Pseudomonas putida [22,23], Bacillus sp. [24] Employment of new techniques for manufacturing of bioplastics that promote sustainable solution and reduce the plastic waste has been greatly encouraged in recent years [25]. Important source of starch is corn but now-a-days, starches from potato, wheat, rice, barley, oat etc. are also being used [26,27,28]. Bio-based plastics can be degraded by algae, fungi and bacteria [29,30,31]. These plastics are novel materials of the 21st century and have great importance [32]. These are currently used as packaging materials, but in future these will be used in forming various products such as electronics and vehicle parts [33]. Figure 1 represents classification of bioplastics [34]. 


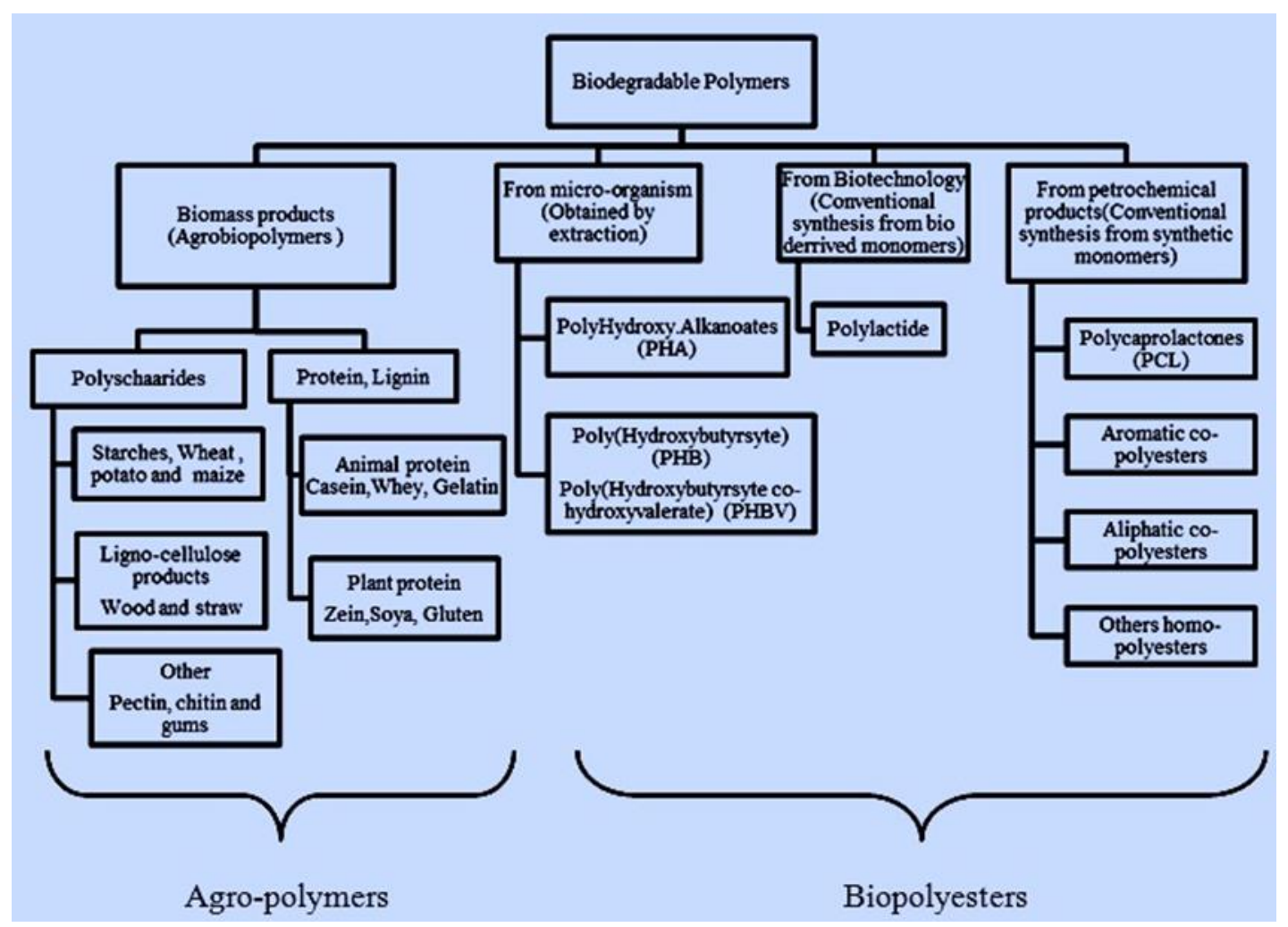

Figure 1 Bioplastic and it's sources

\section{Classification of bioplastic}

Plastics can be manufactured from bio-based or fossil based materials and can be biodegradable or non-biodegradable. While bioplastics are only made from renewable materials, biodegradable plastics are made from fossil based or are made with mixture of renewable and fossil-based materials. Figure 2 represents classification of bioplastic. Three types of Bioplastics are as follows:-

- Biodegradable and Bio-based.

- Biodegradable and fossil-based.

- $\quad$ Non-biodegradable and petroleum based called as plastics [35].

Table 1 Types of bioplastics

\begin{tabular}{|l|l|l|l|}
\hline & Bio based & Petroleum based & Reference \\
\hline Biodegradable & $\begin{array}{l}\text { Bioplastics e.g.:- } \\
\text { Starch, Cellulose, Polyhydroxy } \\
\text { alkanoates, Polylactic acid }\end{array}$ & $\begin{array}{l}\text { Bioplastics e.g.:- } \\
\text { Polycaprolactone, Polybutylene } \\
\text { succinate, Polybutylene adipate } \\
\text { Terephthalate }\end{array}$ & {$[36,37,38,39]$} \\
\hline Non-biodegradable & $\begin{array}{l}\text { Bioplastics e.g.:- } \\
\text { Bio-polyethylene, } \\
\text { polypropylene }\end{array}$ & $\begin{array}{l}\text { Conventional Plastics e.g.:- } \\
\text { PVC, }\end{array}$ & {$[37,38,40]$} \\
\hline
\end{tabular}

Both cellulose and starch are not plastic but can be transformed into plastics by polymer technology or fermentation [41] by using various techniques like casting [42], mixing, extrusion [43], injection molding, etc. [44] Bio-ethylene and Biopropylene have the prefix "bio", indicating that they are made from renewable materials, and have identical properties to that of petrochemical based plastics [45]. Figure: 2 represents classification of bioplastics [46]. 


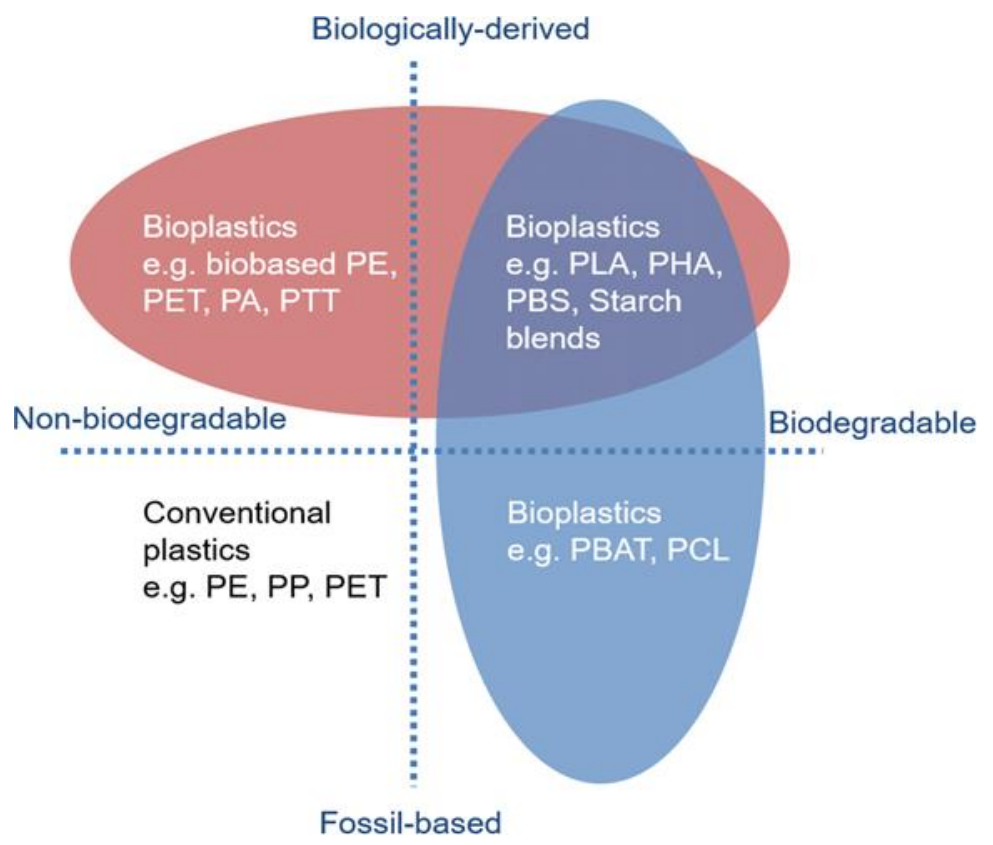

Figure 2 Classification of bioplastic

\section{Bioplastic production}

\subsection{Cellulose}

Cellulose occurs as natural polymer and consists of glucose monomer units that are linked together by Glycosidic linkages. Cellulose is extracted from its crystalline state in microfibrils, it is soluble in solvent such as $\mathrm{N}$ methylmorpholine $\mathrm{N}$-oxide. However, it is quite difficult to use for packaging because of its certain properties like poor solubility, hydrophilic nature and highly crystalline structure. Poor moisture barrier characteristic is present because of alternating hydroxyl side chains along with cellulose. Due to highly crystalline structure, the resulting packaging material is brittle with poor flexibility and tensile strength [47]. As a result, now research has been focused on cellulose derivatives for the purpose of packaging.

\subsection{Cellulose derivatives}

They are polysaccharide consisting of linear chains linked together by beta (1-4) Glucosidic units. Following cellulose derivatives are used for edible films/coating: Hydroxypropyl cellulose, Hydroxypropyl methylcellulose, Carboxymethylcellulose and Methylcellulose. They show thermo-gelation i.e., when suspensions are heated, they form gel and in return gain their original consistency when cooled [48]. Such films are poor water barriers because of hydrophilic nature of molecules, and show poor mechanical properties [49].

One method for improving the quality of moisture barrier can be performed i.e., by addition of hydrophobic compounds such as fatty acids into cellulose matrix to develop the films [50].

\subsection{Starch}

All the green plants produce starch which is white in color, granular, organic chemical, soft, tasteless powder, and insoluble in cold water, alcohol or other solvents. Basic formula of starch is (C6H1005)n [51]. It is polysaccharide consisting of amylose and amylopectin linked together by glycosidic bond [52]. Commercially, starch and its derivatives are produced from various raw materials such as, potato \& its peel, corn, wheat, pea etc. Beyond food industry, it has many applications like, in pharmaceutical sector it is used as binding agent, it has its application in the textile industry, in the paper and board sector [53]. Because of its natural abundance, low cost as well as major carbohydrate content it is considered useful for preparing biodegradable plastics [54]. 


\begin{tabular}{|l|l|l|}
\hline Source & Amylose (in \%) & $\begin{array}{l}\text { Amylopectin (in } \\
\text { \%) }\end{array}$ \\
\hline Banana & 20.5 & 79.5 \\
\hline Potato & 17.8 & 82.2 \\
\hline Corn & 28 & 72 \\
\hline Rice & 35 & 65 \\
\hline Wheat & 20 & 80 \\
\hline
\end{tabular}

In the above table the concentration of amylose and amylopectin present in the various plant products has been mentioned. It is observed that when the concentration of amylose is high the tensile properties of the bioplastic rises [56]. It has been also observed that the biodegradation tendency increases because the amylose molecules loose water and the plasticizer property increases due to the presence of the amylopectin molecules [57].

\subsection{Starch based plastics}

Starch based plastics are safer option than the petroleum based, because they are produced from the natural resources such as corn, potato etc., and are easily degraded. Many countries like Europe have started to implement the idea of starch-based plastics. After degradation, the remaining waste part will be reused and recycled for future use. By using starch-based plastic, we can protect our environment from hazardous chemicals. Commercially $50 \%$ of bioplastics are prepared from the various starches $[3,58]$.

\subsection{Poly-Beta-Hydroxyalkanoates (PHB)}

PHB, degrades under the presence of micro-organism that comes in contact with the polymer, secrete enzymes and breakdown into smaller parts. Properties of PHB are (1) $100 \%$ resistance to water (2) 100\% biodegradability (3) ability to process thermoplastic [1].

\subsection{Polylactide Acid (PLA) Plastics}

PLA is the most attractive material from the packaging point of view, because of its excellent biocompatibility, biodegradable and processing ability. It is processed by injection molding, blow molding, thermoforming \& extrusion. It is composed of lactic acid (2-hydroxy propionic acid) and contains methyl group on alpha $\mathrm{C}$ atoms [59]. Commercially, it was the first biobased polymer on a large scale, which could be shaped into various objects, films [60]. It has replaced HDPE (High density polyethylene), LDPE (Low density polyethylene), PET (Polyethylene terephthalate) \& PS (Polystyrene) as packaging material.

\subsection{Chitin/Chitosan}

It is the second most abundant natural polymer occurring in the nature after cellulose [61]. Chitosan is obtained from Chitin. Chitosan is prepared by deacetylation process in the presence of alkali and it is an important waste of fishery industry [62]. It forms films without any addition of additives, consists of excellent mechanical and microbial properties against bacteria, molds, yeasts. It also exhibits good oxygen \& carbon dioxide permeability, but major drawback is that it has poor solubility in neutral solutions. To obtain a soluble product, the required degree of deacetylation must be 80 85\% [63]. It forms transparent films which improves the quality as well as storage life of the products [64].

\section{Different kinds of plasticizers used for the production of bioplastic:}

Plasticizers are organic molecules, that are added to polymers, to reduce brittleness, reduce crystallinity; improve durability, toughness; lowering melting temperatures [65]. These reduce polymer-polymer contact hence the rigidity of the 3D structures is also reduced, allowing deformation without rupture [6]. In the production of bioplastic, different kind of plasticizers are used that includes polyols such as glycol, glycerol, sorbitol, fructose, sucrose, and mannose, fatty acids such as palmitate or myristate. Out of these, glycerol is most widely studied \& used plasticizer because of its non-toxicity, low cost and high boiling point $\left(292^{\circ} \mathrm{C}\right)$ properties [66]. 


\section{Bioplastic from uneatable substances}

In today's world where food is a scare resource, we can produce bioplastics from non-edible portions too. Things such as orange peel, pomegranate peel, banana peel, potato peel are used for the production of bioplastic. In the latest trend bioplastic films from polysaccharide residue feedstock is in great demand. Cellulose, hemicelluloses, starch, pectin make these lignocellulosic feedstocks useful for the production of bioplastic.

\subsubsection{Pomegranate peel}

Has rich source of bioactive compounds [67]. It consists of lignin-5.7\% and hemicelluloses-10.8\%, cellulose-26.2\% and pectin-27\%. On acid hydrolysis, the polysaccharides present in peel are converted into monosaccharides which can break down into cellulose, hemicelluloses and lignin components. These components further are used to develop bioplastic [25].

\subsubsection{Orange peel}

The peel contains carbohydrates which can be used for the production of biomolecules. Careless discharge of unprocessed peels causes many environmental problems [25]. Therefore, it is recommended to collect the waste and convert it into bioplastics.

\section{Life cycle of bioplastic}

Figure 3 shows life cycle of bioplastic

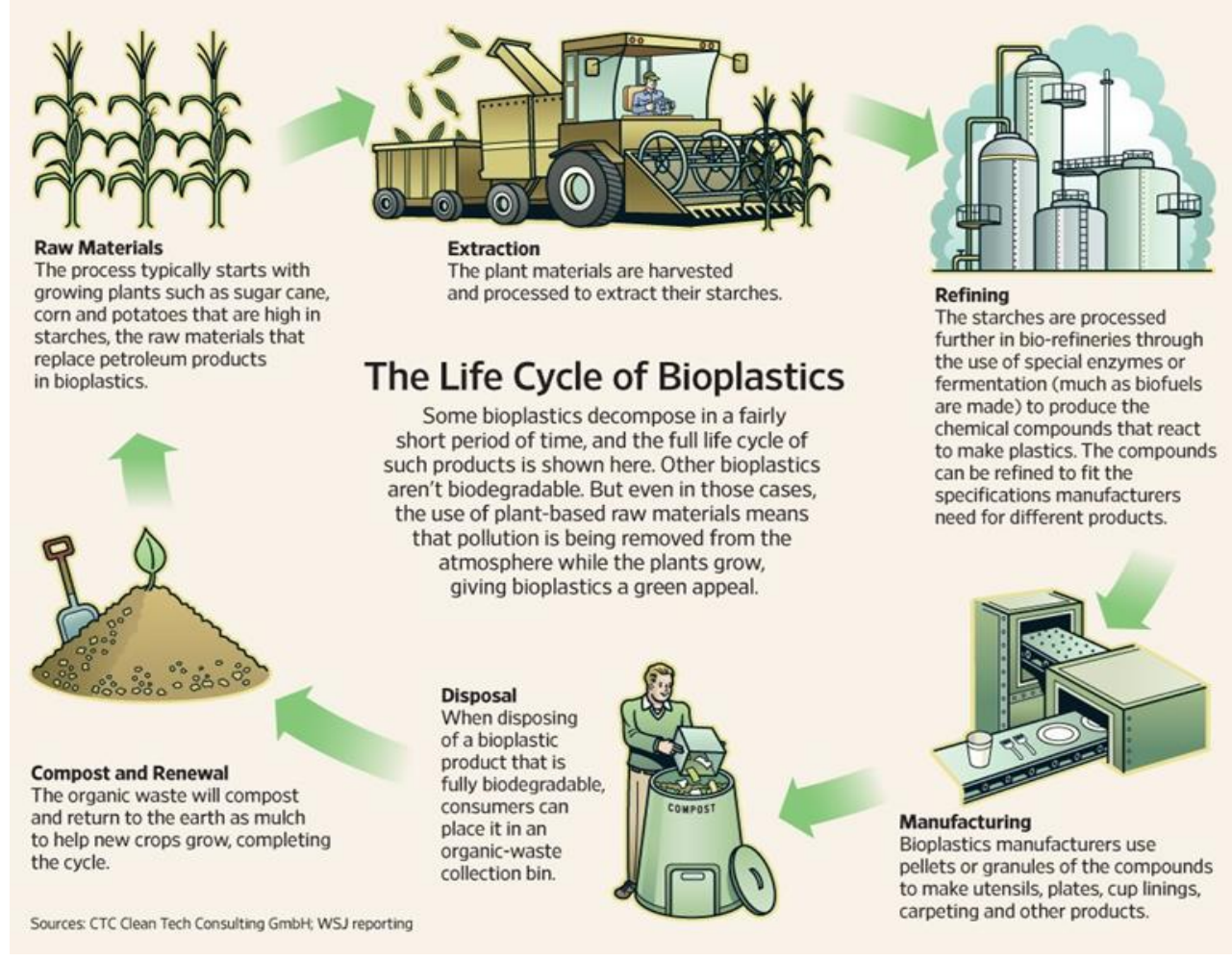

Figure 3 Lifecycle of bioplastic (http://www.sciepub.com/reference/84613)

\section{Bioplastic market}

Figure 4 represents the lifecycle of bioplastic[69]. This figure depicts how bioplastic production and degradation goes on simultaneously. Many researchers have developed tools to assist in decision making about the selection of plastic. One of them is the "Plastic spectrum" [68,69]. 


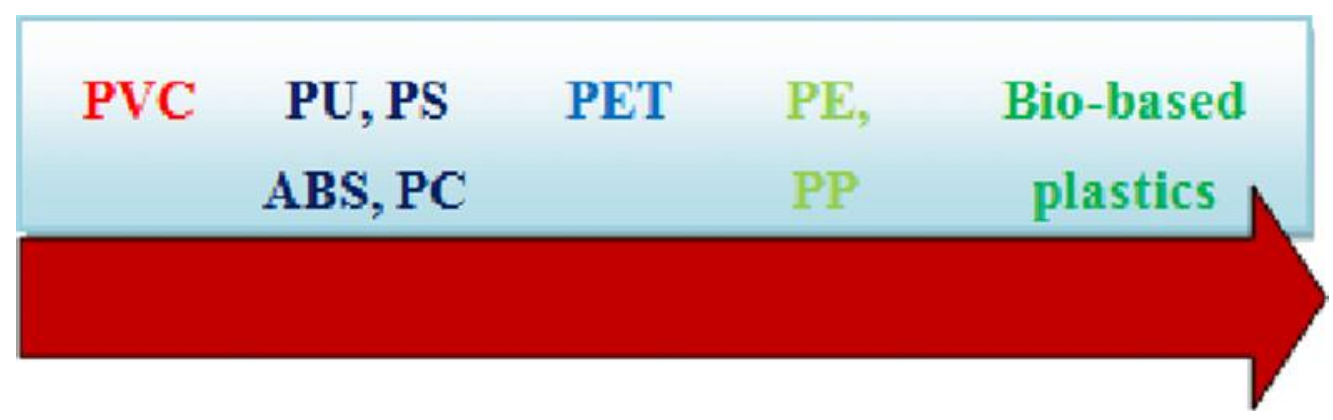

Figure 4 Plastic spectrum

In this spectrum, Bio-based bioplastics indicate that they are more preferable, as they are produced from renewable sources, they are biodegradable and compostable [70]. Bioplastic containers and packaging films and are more appropriate option because these products have a relative short service life and easily end up in landfills. Biodegradable bioplastics have many applications in the biomedical field like in drug delivery carriers, tissue engineering scaffolds and in making bone plates and screws [68,71]. McDonald in America already started to make biodegradable containers for their fast-food service and delivery. Many companies like Dupont, Nike, Danone, Bayer, Dow Cargill etc. are producing biodegradable packaging materials [72].

About 20\%-25\% per year global bioplastic market is growing. In 2020, approximately 10\%-15\% bioplastics of the total plastics market increased and its share went up to 25\%-30\%. The bioplastic market reached up to 1 billion US\$ in 2007 and 10 billion in 2020. Many companies are investing in bioplastic market which is a good indication for our environment.

\subsection{Advantages and Disadvantages of bioplastic}

Plastic is the main pollutant in the environment which is used on the daily basis [73]. Therefore, to decrease environmental pollution, we should switch to bioplastic rather than the petrochemical based products. By doing this, many environmental issues can be solved [74]. Bioplastics have unique characteristics such as eco-friendly, compostable, biodegradable as well as energy efficient [75].

Future of biodegradable plastics shows great potential. Here are some of the advantages of the bioplastics:

- $\quad$ Reduced carbon foot print $[33,75,76]$.

- $\quad$ Energy efficiency $[33,75,76]$.

- $\quad$ Partly based on natural feedstock [33,75,77].

- $\quad$ Eco-safety [78].

However, problems might occur with the use of bioplastics. Here are some of the disadvantages of bioplastics:

- $\quad$ High cost $[77,79]$.

- $\quad$ Brittleness [37,80].

- Thermal instability [33,80].

- $\quad$ Various recycling problems [77].

\subsection{Applications}

Bioplastics are used as packaging material for both short shelf-life products like vegetables and fresh fruits, and long shelf-life products, like potato chips and pasta [80].

Applications of bioplastic based on the materials from which they are prepared are as follows-

- $\quad$ Cellulose - packaging, disposal household, electronic devices [81,82,83,85].

- $\quad$ Starch - food packaging, agriculture foils, textiles and construction $[83,84,85,86]$.

- $\quad$ PLA - films, food packaging $[88,89]$

- $\quad$ PHA - food packaging $[75,87,88]$. 
Table 2 Current applications of bioplastic [80] based on biopolymer are listed as follows-

\begin{tabular}{|c|c|c|}
\hline Packaging & Biopolymer & Company \\
\hline \multicolumn{3}{|l|}{ Starch based } \\
\hline Milk Chocolates & Cornstarch trays & Cadbury Schwepps \\
\hline Organic Tomatoes & Corn-based packaging & $\begin{array}{l}\text { Iper } \\
\text { Supermarkets (Italy) Coop Italia }\end{array}$ \\
\hline \multicolumn{3}{|l|}{ Cellulose based } \\
\hline Kiwi & $\begin{array}{l}\text { Bio-based } \quad \text { trays } \\
\text { wrapped }\end{array}$ & Wal-Mart \\
\hline Organic Pasta & $\begin{array}{l}\text { Cellulose } \quad \text { based } \\
\text { packaging }\end{array}$ & Birkel \\
\hline Sweets & $\begin{array}{l}\text { Metalized cellulose } \\
\text { film }\end{array}$ & Qualitystreet, Thomton \\
\hline Potato chips & $\begin{array}{l}\text { Metalized cellulose } \\
\text { film }\end{array}$ & Boulder Canyon \\
\hline \multicolumn{3}{|l|}{ PLA } \\
\hline Beverages & PLA cups & Mosburger (Japan) \\
\hline Yogurt & PLA jars & Stonyfield (Danone) \\
\hline Bread & $\begin{array}{l}\text { Paper bags with PLA } \\
\text { Window }\end{array}$ & Delhaize (Retailer) \\
\hline Fresh salads & PLA bowls & McDonald's \\
\hline
\end{tabular}

\section{Conclusion}

This review has covered classification, sources, life cycle, advantages, disadvantages and applications of bioplastic. Utilization of renewable resources for the production of bioplastics rather than Petro-chemical ones are more beneficial for our environment as well as for other lives on the earth. Since Petro-chemical based plastics have many disadvantages i.e., they cause environment pollution, from the manufacturing to recycling they produce toxic gases, etc. Moreover, eating food from plastic containers may cause cancer as it is widely used in packaging. We should switch to bioplastic, as it is renewable, bio-degradable, eco-friendly and sustainable option in comparison to Petro-chemical plastics. Hence, the research and development in the field of bioplastics is much needed \& should been encouraged.

\section{Compliance with ethical standards}

\section{Acknowledgments}

I would like to say special thanks to Himanshu A. Pandya, Archana U. Mankad and Sanjukta Rajhans. They always gave me the opportunities to learn and grow. I feel fully fortunate to study, work and research at Department of Botany, Bioinformatics and Climate Change Impacts Management, School of Science, Gujarat University.

\section{Disclosure of conflict of interest}

Hereby I declare there is no author conflict. 


\section{References}

[1] Kumar Y, Shukla P, Singh P, Prabhakaran PP, Tanwar VK. Bioplastics: A perfect tool for Eco-friendly Food Packaging: A Review. Journal of Food Product Development and Packaging. 2014; 1(1): 01-06.

[2] Chisti Y. How renewable are the bioplastics?. Biotechnology Advance. 2014; 32(7):1361.

[3] Gadhave RV, Das A, Mahanwar PA, Gadekar PT. Starch based bioplastics : The Future of Sustainable Packaging. Open Journal of Polymer Chemistry. 2018; 8(2): 21-23.

[4] Boonniteewanich J, S Pitivut, S Tongjoy, S Lapnonkawow, S Suttiruengwong. Evaluation of carbon footprint bioplastics straw compared to petroleum based straw products. In Proc. 11th Eco-Energy and Materials Science and Engineering (11th EMSES), Energy Procedia. 2014; 56(1): 518-524.

[5] Sushmitha BS, Vanitha KP, Rangaswamy BE. Bioplastics - A Review. International Journal of Modern Trends in Engineering and Research. 2016; 3(4): 411-413.

[6] Mekonnen T, P Mussone, H Khalil, D Bressler. Progress in bio-based plastics and plasticizing modifications. Journal of Material Chemistry A. 2013; 43(1): 13379-13398.

[7] Barker T. In Climate Change 2007: Mitigation. Contribution of Working Group III to the Fourth Assessment, Report of the Intergovernmental Panel on Climate Change. 2010, USA: Cambridge University Press. IPCC, Geneva, Switzerland. 104.

[8] Thompson RC, CJ Moore, FS Vom Saal, SH Swan. Plastics, the environment and human health: current consensus and future trends. Philosophical Transactions of the Royal Society B. Biological Sciences. 2009; 364(1523): 21532166.

[9] Mathieu-Denoncourt Justine, Wallace Sarah j, de Solla Shane R,Langlois Valerie S. Plasticizer endocrine disruption: Highlighting developmental and reproductive effects in mammals and non-mammalian aquatic species. General and Comparative Endocrinology. 2015; 219(1): 74-88.

[10] Barnes DKA, Galgani F, Thompson RC, Morton. Accumulation and fragmentation of plastic debris in global environments. Philosophical Transaction of the Royal Society B: Biological Sciences. 2009; 364(1526): 19851998.

[11] Kuruppalil Z. Green Plastics: An Emerging Alternative for Petroleum based plastics. International Journal of Engineering Research and Innovation. 2011; 3(1): 59-64.

[12] Swati Pathak, CLR Sneha, Blessy Baby Mathew. Bioplastics: Its Timeline Based Scenario and Challenges. Journal of Polymer and Biopolymer Physics Chemistry. 2014; 2(4): 84-90.

[13] Philippe Chalmin. The history of plastics from the Capitol to the Tarpeian rock. Field Actions Science Reports. The Journal of field actions. 2019; 19.

[14] Siracusa V, Rocculi P, Romani S, Dalla Rosa M. Biodegradable polymers for food packaging. Trends in Food Science \& Technology. 2008; 19(12): 634-643.

[15] Sudesh K, Iwata T. Sustainability of biobased and biodegradable plastics. CLEAN - Soil, Air, Water. 2008; 36(56): 433-442.

[16] Souza AC, Benze R, Ferrão ES, Ditchfield C, Coelho ACV, Tadini CC. Cassava starch biodegradable film: Influence of glycerol and clay nanoparticles content on tensile and barrier properties and glass transition temperature. LWT - Food Science and Technology. 2012; 46(1): 110-117.

[17] Navarro YM, Soukup K, Jandová V, Gómez MM, Solis JL, Cruz JF, Cruz GJF.. Starch/chitosan/glycerol/ films produced from low value biomass: effect of starch source and weight ratio on film properties. In Journal of Physics: Conference series. 2019 February; 1173(1), 012008.

[18] Joshi SGG, Sharm U, Goswami G. Bio-plastic from Waste Newspaper. International Journal of Engineering Research and Technology ETRASCT 14 Conference Proceedings 2014; 2(3): 24-27.

[19] Kasirajan S, Umapathy D, Chandrasekar C, Aafrin V, Jenitapeter M, Udhyasooriyan L, Muthusamy S. Preparation of poly (lactic acid) from Prosopis juliflora and incorporation of chitosan for packaging application. Journal of bioscience and bioengineering. 2019; 128(3): 323-331.

[20] Batori V, Jabbari M, Akesson D, Lennartsson PR, Taherzadeh MJ, Zamani A. Production of Pectin Cellulose Biofilms: A New approach for Citrus Waste Recycling. International Journal of Polymer Science. 2017; 9(9): 1-9. 
[21] Bhati R. Biodegradable Plastics Production by Cyanobacteria. In Biotechnology Products in Everyday Life. Springer, 1st edition. 2019; 250.

[22] Gatea IH, Abbas AS, Abid AG, Halob AA, Maied SK, Abidali AS. Isolation and characterization of Pseudomonas putida producing bioplastic (Polyhydroxyalkanoate) from vegetable oil waste. Pak J Biotechnology. 2018; 15(2): 469-473.

[23] Hadisoewignyo L, Foe K, Tjandrawinata RR. Isolation and characterization of Agung banana peel starch from East Java Indonesia. International Food Research Journal. 2017; 24(3):1324-1330.

[24] Alshehrei F. Production of polyhydroxybutyrate (PHB) by Bacteria Isolated from Soil of Saudi Arabia. Journal Pure Applied Microbiology. 2019; 13(2): 897.

[25] Chozhavendhan S, Usha P, Sowmiya G, Rohini G. A review on bioplastic production A Need to the Society. International Journal of Pharmaceutical Sciences Review and Research. 2020; 62(1): 27-32.

[26] Guilbert S, Cuq B, Gontard N. Recent innovations in edible and/or biodegradable packaging materials. Food Additives and Contaminants. 1997; 14(6-7): 741-751.

[27] Scott G, Wiles DM. Programmed-life plastics from polyolefins: A new look at sustainability. Biomacromolecules. $2001 ; 2(3): 615-622$.

[28] Song JH, Murphy, RJ, Narayan R, Davies GBH. Biodegradable and compostable alternatives to conventional plastics. Philosophical transactions of the royal society B: Biological Sciences. 2009; 364: 2127-2139.

[29] Ali S, Zaki NH, Yassen N, Obiad S. Production of bioplastic by bacteria isolated from local soil and organic wastes. Current Resources in Microbiology and Biotechnology. 2017; 5(2): 1012-1017.

[30] Das SK, Sathish A, J Stanley J. Production of Biofuel and Bioplastic from Chlorella Pyrenoidosa. Materials Today: Proceedings. 2018; 5(8): 16774-16781.

[31] Momani B. Assessment of the Impacts of Bioplastics: Energy Usage, Fossil Fuel Usage, Pollution, Health Effects, Effects on the Food supply, and Economic Effects Compared to Petroleum Based Plastics. Worcester Polytechnic Institute. 2009.

[32] Mohanty AK, Misra M, Drzal LT. Sustainable Bio-composites from Renewable Resources: Opportunities and Challenges in the Green Materials World. Journal of Polymers and the Environment. 2002; 10(1-2): 19-26.

[33] Chen YJ. Bioplastic and their role in achieving global sustainability. Journal of Chemical and Pharmaceutical Research. 2014; 6(1): 226-231.

[34] O Vilpoux,L Averous. in M. P. Cereda and O. Vilpoux,eds., Technology, Use and Potentialities of Latin American Starchy Tubers, NGO Raizes and Cargill Foundation, Sao Paolo, Brazil. 2004; 521-553.

[35] Izathul Shafina Sidek, Sarifah Fauziah Syed Draman, Siti Rozaimah Sheikh Abdullah, Nornizar Anuar. Current Development on Bioplastics And Its Future Prospects: An Introductory Review. iTECH MAG. 2019; 1(1): 03-08.

[36] Mohapatra A, Prasad S, Sharma H. Bioplastics - Utilization of Waste Banana Peels for synthesis of Polymeric Films. 2015

[37] Ilyas RA, Sapuan SM, Sanyang ML, Ishak MR. Nanocrystalline cellulose reinforced starch based nanocomposite: A review Conference: 5 th postgraduate senior on natural fiber composites. At University Putra Malaysia. 2016; 8287.

[38] Soykeabkaew N, Tawichai N, Thanomsilp C, Suwantong O. Nanocellulose Reinforced Green Composite Materials. Walailak Journal Science \& Technology. 2017; 14(5): 353- 368.

[39] Lackner M. Bioplastics - Biobased plastics as renewable and/or biodegradable alternatives to petroplastics. Kirk-Othmer Encyclopedia of Chemical Technology. 2015.

[40] Emadian SM, Onay TT, Demirel B. Biodegradation of bioplastics in natural environments. Waste Management. 2017; 59(1): 526-536.

[41] Misra M, Nagarajan V, Reddy J, Mohanty AK. Bioplastics and Green Composites from Renewable Resources: Where We are and Future Directions!. 18th International Conference on Composite Materials. 2009; 1-5.

[42] Indriyati, Yudianti R, Karina M. Development of Nanocomposites from Bacterial Cellulose and Poly(vinyl alcohol) using casting drying method. Procedia Chemistry. 2012; 4(1): 73-79.

[43] Wang B. Pre-treatment of Flax Fibers for use in rotationally molded biocomposites. Journal of reinforced plastics and composites 2007; 26(5): 447-463. 
[44] Salleh MSN, Saadon N, Razali N, Omar Z, Khalid SA, Mustaffa AR, Yashim MM, Rahman WAWA. Effects of Glycerol content in modified polyvinyl alcohol- tapioca starch blends. IEEE Symposium on Humanities, Science and Engineering Research, Kuala Lumpur. 2012; 523-526.

[45] Jovanoviæ S, Dpunuzoviæ JV, Stojanoviæ Y. Polymers based on Renewable Raw Materials - Part I. Kem. Ind. 2013; 62(9-10): 307-314.

[46] Elias HG. An introduction to plastics. Weinheim: VCH. Polymer International. 1994; 34(2): 237-238.

[47] Jamshidi K. Hyon SH and Ikada Y. Thermal characterization of polylactides. Polymer. 1998; 29(12): $2229-2234$.

[48] Murray JCF. In: Philips GO, Williams PA(eds) Handbook of hydrocolloids. CRC Press LLC. Boca Raton Boston New York Washington, DC Woodhead Publishing Limited. 2002; 219- 229.

[49] Gennadios A, Weller CL, Testin RF. Property modification of edible wheat, gluten based films. Transactions of the ASAE. 1993; 36(2): 465-470.

[50] Morillon V. Debeaufort F, Blond G, Capelle M, Voilley A. Factors affecting the moisture permeability of lipid based edible films: A Review. Critical Reviews in Food Science and Nutrition. 2002; 42(1): 67-89.

[51] Jane JJ MS. Starch properties, modifications, and applications. Journal of Macromolecular Science, Part A: Pure and Applied Chemistry. 1995; 32(4): 751-757.

[52] Jariyasakoolroj P, Leelaphiwat P, Harnkarnsujarit N. Advances in research and development of bioplastic for food packaging. Journal of the Science of Food and Agriculture. 2018; 100(14): 5032-5045.

[53] Laycock BG, Halley PJ. Starch applications: State of market and new trends. In Starch polymers from genetic engineering to green applications.2014; 381-419.

[54] Gáspár M, Benko Z, Dogossy G, Réczey K, Czigány T. Reducing water absorption in compostable starch based plastics. Polymer Degradation and Stability. 2005; 90(3): 563-569.

[55] Young AH. Fractionation of starch. In Starch: Chemistry and Technology (Second Edition); Elsevier: Amsterdam, The Netherland. 1984; 249-283.

[56] Ceseracciu L, Heredia-Guerrero JA, Dante S, Athanassiou A,Bayer IS. Robust and biodegradable elastomers based on corn starch and polydimethylsiloxane (PDMS). ACS Appl. Mater. Interfaces. 2015; 7(6): 3742-3753.

[57] Verma D, Gope PC, Maheshwari MK, Sharma RK. Bagasse fiber composites- A review. J. Mater. Environm. Sci. 2012; 3(6): 1079-1092.

[58] Abidin MZAZ, Julkapli M, Juahir H, Azaman F, Sulaiman NH,Abidin IZ. Fabrication and properties of chitosan with starch for packaging application. Malays. J. Anal. Sci, 2015; 19(5): 1032-1042.

[59] Hakola J. Proceedings of renewable bioproducts: Industrial outlets for the 21st century. EC Symposium held in Wageningen, Holland. Section 4.1997

[60] Rasal RM, Janorkar AV, Hirt DE. Polylactic acid modifications. Progress in Polymer Science. 2010; 35(3): 338-356.

[61] Shahidi F, Arachchi JKV, Jeon YJ. Food applications of chitin and chitosans. Trends in Food Science and Technology. 1999; 10(2): 37-51.

[62] Sánchez GL, Chelo GM, Amparo C, Maite C. Physical and antimicrobial properties of chitosan - tea tree essential oil composite films. Journal of food Engineering. 2010; 98(4): 443- 452.

[63] Park H, Li X, Jin C, Park CY, Cho WJ. Preparation and properties of biodegradable thermoplastic starch/clay hybrids. Macromolecular Materials and Engineering. 2002; 287(8): 553-558.

[64] Ribeiro C, Vicente AA, Teixeira JA, Miranda C. Optimization of edible coating composition to retard strawberry fruit senescence. Postharvest Biology and Technology. 2007; 44(1): 63-70.

[65] De Groote PH, Devaux J, Godard P. Effect of benzenesulfonamide plasticizers on the glass-transition temperature of semicrytalline polydodecamide. Journal of Polymer Science Part B: Polymer Physics. 2002; 40(19): $2208-2218$.

[66] Forssell PM, Mikkila JM, Moates GK, Parker R. Phase and glass transition behavior of concentrated barley starch glycerol water mixtures, a model for thermoplastic starch. Carbohydrate Polymers. 1997; 34(4): 275-282.

[67] Malgorzata Gumienna, Artur Szwengiel, Barbara Gorna. Bioactive components of pomegranate fruit and their transformation by fermentation processes. European Food Research and Technology. 2016; 242(5): 348.

[68] Kaith BS, Jindal R, Jana AK, Maiti M. Development of Corn Starch Based Green Composites Reinforced with Saccharum Spontaneum L Fiber and Graft Copolymers - Evaluation of Thermal, Physio-chemical and Mechanical Properties. Bioresource Technology. 2010; 101(17): 6843-6851. 
[69] Iles A, Martin AN. Expanding Bioplastics Production: Sustainable Business Innovation in the Chemical Industry. Journal of Cleaner Production. 2013; 45(1):38-49.

[70] Alvarez-Chavez CR, Edwards S, Moure-Eraso RL, Geiser K. Sustainability of bio-based plastics: General Comparative Analysis and Recommendations for Improvement. Journal of Cleaner Production. 2011; 23(1): 467.

[71] Sivan A. New Perspectives in Plastic Biodegradation. Current Opinion in Biotechnology. 2011; 22(3): 422-426.

[72] Krzan A, Hemjinda S, Miertus S, Corti A, Chiellini E. Standardization and Certification in the Area of Environmentally Degradable Plastics. Polymer Degradation and Stability. 2006; 91(12): 2819-33.

[73] Pradhan S. Optimization and Characterization of Bioplastic Produced by Bacillus Cereus SE1. National Institute of Technology Rourkela, Odisha. 2014.

[74] Kalia S, Dufresne A, Cherian BM, Kaith BS, Av'erous L, Njuguna J, Nassiopoulos E. Cellulose based bio- and nanocomposites: A review. International Journal of Polymer Science. 2011; 3(3): 1-35.

[75] Shamsuddin IM, Jafar JA, Shawai ASA, Yusuf S, Lateefah M, Aminu I. Bioplastics as Better Alternatives to Petroplastics and Their Role in National Sustainability: A Review. Advances in Bioscience and Bioengineering. 2017; 5(4): 63-40.

[76] Reddy RL, Reddy VS, Gupta GA. Study of Bioplastics as Green \& Sustainable Alternative to Plastics. International Journal of Emerging Technology and Advanced Engineering. 2013; 3(5): 82-89.

[77] Arikan EB, Ozsoy HD. A Review: Investigation of Bioplastics. Journal of Civil Engineering and Architecture. 2015; 9(2): 188-192.

[78] Yu J, Chen LXL. The Greenhouse Gas Emissions and Fossil Energy Requirement of Bioplastics from Cradle to Gate of a Biomass Refinery. Environmental Science and Technology. 2008; 42(18): 6961-6966.

[79] Shivam P. Recent Developments on biodegradable polymers and their future trends. International Research Science Eng. 2016; 4(1): 17-26.

[80] Nafisa Jabeen N, Majid I, Nayik GA. Bioplastics and Food Packaging: A Review. Cogent Food \& Agriculture. 2015; 42(1): 01-06.

[81] Kumar S, Thakur KS. Bioplastics - Classification, production and their potential food application. Journal of Hill Agriculture. 2017; 8(2): 118-129.

[82] Mehta Varda, Darshan M, Nishith D. Can a Starch Based Plastic Be an option of Environmental Friendly Plastic? Journal of Global Biosciences. 2014; 3(3): 681-685.

[83] Sabbah M, Porta R. Plastic Pollution and the challenge of bioplastics. Journal of Applied Biotechnology \& Bioengineering Opinion. 2017; 2(3): 111.

[84] Modi VK, Shrives Y, Sharma C, Sen PK, Bohidar SK. Review on Green Polymer Nanocomposite and their Applications. International Journal of Innovative Research in Science, Engineering and Technology. 2014; 3(11): 17651-17656.

[85] Barker M, Safford R. Industrial uses for crops: Markets for Bioplastics. HGGA. 2009.

[86] Orts WJ, Shey J, Imam SH, Glenn GM, Guttman ME, Revol JF. Application of cellulose microfibrils in polymer nanocomposites. Journal of Polymers and the Environment. 2005; 13(4): 301-306.

[87] Brodin M, Vallejos M, Tanase M, Chinga-carrasco, G. Lignocellulosics as sustainable resources for production of bioplastics - A Review. Journal of Cleaner Production. 2017; 162(1): 646-664.

[88] Khosravi-DaraniK, Bucci DZ. Application of Poly(hydroxyalkanoate) in Food Packaging: Improvements by Nanotechnology. Chemical and Biochemical Engineering Quarterly. 2015; 29(2): 275-285.

[89] Beucker S, Marscheider-weidemann F. Potentials and Challenges of Bioplastics Insights from a German Survey on “Green" Future markets. In Hilty, L. M., Edelmann, X. and Ruf, A. (Eds.) R'07 World Congress, September 3-5, Davos, Switzerland. St. Gallen: EMPA.2007. 